\title{
MARKETING STRATEGY ENTREPRENEUR BASED OF PT. GILI ENCHANTING PROSPERITY THROUGH THE NORTH LOMBOK TOURISM INDUSTRY
}

Oleh:

\author{
Samsudin 1 \\ Didin Hadi Saputra
}

Email:

didinimarc@gmail.com

\begin{abstract}
This qualitative descriptive study aims to describe the marketing strategy of PT. Gili Pesona Sejahtera in increasing revenue through the tourism industry in Gili Trawangan, Regency of Winner, Regency of North Lombok in 2018. with PT. Gili's Persona Sejahtera as respondent Data collection uses observation, interview, and documentation methods. Data analysis techniques using the Miles and Huberman models which include data reduction, data presentation (data display), and verification (concluding). the results showed that the marketing strategy of PT. Gili Pesona Sejahtera in its operations collaborates with accommodation entrepreneurs including hoteliers, travel agent entrepreneurs, water entrepreneurs, internet marketing entrepreneurs, and offline space guides. PT. Gili Pesona Sejahtera implements a mutually beneficial partnership in the form of providing a fee of $10 \%$ of the total selling price of rooms with partners who are able to lobby travelers.
\end{abstract}

Keywords: marketing strategy, income

\begin{abstract}
ABSTRAK
Penelitian deskriptif kualitatif ini bertujuan untuk menggambarkan strategi pemasaran PT. Gili Pesona Sejahtera dalam meningkatkan pendapatan melalui industri pariwisata di Gili Trawangan, Kabupaten Pemenang, Kabupaten Lombok Utara pada tahun 2018. Dengan PT. Gili's Persona Sejahtera sebagai responden pengumpulan data menggunakan metode observasi, wawancara, dan dokumentasi. Teknik analisis data menggunakan model Miles dan Huberman yang meliputi reduksi data, penyajian data (tampilan data), dan verifikasi (menyimpulkan). Hasil penelitian menunjukkan bahwa strategi pemasaran PT. Gili Pesona Sejahtera dalam operasinya bekerja sama dengan pengusaha akomodasi termasuk pelaku bisnis perhotelan, pengusaha agen perjalanan, pengusaha air, pengusaha pemasaran internet, dan panduan ruang offline. PT. Gili Pesona Sejahtera menerapkan kerjasama saling menguntungkan dalam bentuk pemberian fee $10 \%$ dari total harga jual kamar dengan para mitra yang mampu melobi para pelancong.
\end{abstract}

Kata Kunci: strategi pemasaran, pendapatan 


\section{A. INTRODUCTION}

The hospitality industry is one aspect that has an important role in the development of tourism in Lombok, West Nusa Tenggara, one of which is the hospitality that provides accommodation services for tourists. The number of tourist visits that have increased influences the development of the hotel industry because the increase in the number of tourist visits will also increase the need for accommodation services, especially hotels as a supporting tool. Every company has a goal to stay alive and develop; these objectives can only be achieved through efforts to maintain and increase the level of profit/profit of the company (GiménezMeseguer et al., 2020). This business can only be done if the company can maintain and increase the profit/profit level of the company. This business can only be done if the company can maintain and increase its sales, through an effort to find and foster subscriptions, as well as efforts to dominate the market.

From these conditions, the highly competitive climate did not always make business actors in the tourism sector threaten the survival of their business, but it was used to establish mutually beneficial cooperation between the two parties, as was done by PT. Gili Pesona Sejahtera. PT. Gili Pesona Sejahtera is a company engaged in hospitality that cooperates with various types of tourism industry entrepreneurs such as; lodging operators from small to starred hotels, entrepreneurs travel agents, water tourism entrepreneurs, internet marketing entrepreneurs, and offline/freelance room guides. For the company to be able to compete with other companies, the company management must be able to process the company well and do various ways to attract consumers or customers to come and use the facilities offered so that the existing target customers or customers do not switch to other companies.

Preparation of the right strategy is a factor that greatly determines the success of a company in realizing its vision and mission, as well as with PT. Gili Pesona Sejahtera as one of the companies engaged in lodging accommodation services that offer a variety of additional packages and collaborates with various other accommodation service providers to win the competition in marketing their products and services. Based on the description above, researchers are interested in researching: "Marketing Strategy of PT. Gili Enchanting Prosperity Through the North Lombok Tourism Industry ". The purpose of this study was to find out the Marketing Strategy of PT. Gili Pesona Sejahtera in Increasing Revenue Through Tourism Industry in Gili Trawangan, Pemenang District, North Lombok Regency in 2018 ".

\section{B. LITERATURE REVIEW}

Strategy is an action that is incremental (always increasing) and continuously, and is done based on the point of view of what is expected by customers in the future. Thus, the strategy almost always starts from "what can happen" and does not start from "what happened" (Haidari et al., 2013). The occurrence of the speed of new market innovations and changes in consumer patterns requires core competencies. Companies need to look for core competencies in the business that they do. (Njoku \& Cooney, 2020), the strategy is defined as a process of 
determining the plans of top leaders who focus on the long-term goals of the organization, accompanied by the preparation of a way or effort to achieve that goal.

\section{Understanding of Marketing}

The term Marketing can be interpreted in various contexts under the development of the strategies carried out by the company (Rahim et al., 2019). The widely accepted and well-known marketing term as a marketing concept is marketing that is based on the introduction of consumer needs. With this concept, marketing can be interpreted as all activities that are directed to recognize and fulfill or satisfy the needs and desires of consumers or customers. (Figueiredo et al., 2019) defines marketing as a social process where each individual and group gets what they need and want by creating and exchanging products and values with other individuals or groups. In other words, marketing is a human activity to satisfy human needs and desires through an exchange process.

Whereas according to (Ardelean et al., 2020) marketing is an overall system of business activities aimed at planning, pricing, promoting, and distributing goods and services that satisfy the needs of both existing buyers and potential buyers. The marketing definition stated by the expert can be seen that marketing is a system of business activities that are interconnected and aimed at planning, creating, distributing, and promoting goods and services carried out by the company to meet the wants and needs of consumers.

\section{Understanding Services}

(Services are every action or performance that can be offered by one party to another, which is intangible and does not result in ownership of something. Services are economic activities whose outputs are not products consumed together with the time of production and provide added value (such as enjoyment, entertainment, relaxation, health) are intangible (Xu et al., 2019).

\section{Service Marketing Mix}

Services are activities or benefits that can be offered by one party to another and do not result in the transfer of ownership. Services are intangible, inseparable, volatile, and not durable. Every characteristic has a problem and requires a strategy. On the marketing of services, a strategic approach is directed at the ability of marketers to find ways to realize intangible ones, increase inseparable provider productivity of the product, create quality standards due to variability, and influence movement of demand and supplier capacity given that services are not durable. In general, service marketing strategies are applied in the context of the company as a whole, not only requires external marketing, but also internal marketing to motivate employees and interactive marketing to create service provision expertise. Marketing in a company results in customer satisfaction and long-term consumer welfare as the key to get profit/profit. This applies to companies engaged in the service industry and non-service industries. Even though there are similarities in objectives in both types of industries, different marketing 
strategies are needed for each type of industry. The difference in strategy is influenced by different basic characteristics of the type of product produced (Suprapto, 2019).

According to (Hurriyati, 2010, p. 48), the definition of the marketing mix is marketing elements that are interrelated, mixed, organized, and used appropriately so that the company can achieve marketing objectives effectively while satisfying the needs and desires of consumers. According to Zeithalm and Bitner in (Hurriyati, 2010, p. 48) states that the traditional marketing mix concept (traditional marketing mix) consists of $4 \mathrm{P}$, namely: product (product), price (price), location (place) and promotion (promotion). To plan offers or products, marketers need to understand the product level, which is: a) Core/core products, b) Generic products, c) Product expectations (expected product), d) Complementary products (augmented product), e) Potential products.

\section{Service Rates / Prices (Price)}

The principles of pricing according to Zeithalm and Bitner in (Hurriyati, 2010, p. 52) are as follows: Companies must consider several factors in setting prices; Companies do not have to always try to find maximum profit through maximum pricing; Marketers should understand how responsive demand is to price changes; Various types of costs must be considered in setting prices; The prices of competitors will affect the level of demand for services; There are various ways or variations in pricing that include, target acquisition, acceptable values, psychological factors, and other prices; After setting the price structure, the company adjusts the price by using psychological prices, discounted prices, promotional prices, and the price of the product mix.

According to Zeithhalm and Bitner in (Hurriyati, 2010, p. 54), states that there are three bases for setting prices commonly used in determining prices, namely: Cost-based pricing; Competition-based pricing; Pricing based on demand (demandbased).

\section{Place}

The Place attachment is significant in tourism marketing as it influences revisit intentions and destination loyalty. The memorable tourism experiences significantly influences place attachment, and that hedonic and eudaimonic wellbeing fully mediates this relationship. Tourists develop an attachment to a destination when their experience is memorable, satisfying and enhances their purpose and meaning in life (Vada et al., 2019). Place brands are an influential marketing axiom in tourism (Matiza \& Slabbert, 2020). Brand loyalty positively influences people's emotional attachment to the associated place. Affective destination image mediates the effect of brand loyalty on place attachment. For people from a distance culture, the effect of brand loyalty on place attachment is stronger (Liu et al., 2020). In tourism, Place identity proved to be an effective tool in measuring resident attitudes in the aspect of esteem and efficacy (Wang \& Xu, 2015). 


\section{Promotion (Promotion)}

A number of studies explain how important promotion is in the tourism industry. Effective promotional activities are essential in the development of tourism in an area (Betari Avinda et al., 2016) . (Dudensing et al., 2011) explain that in general, tourism businesses and support organizations agree on the promotional needs of tourism-based businesses and hold similar perceptions about industry problems. However, (Durst \& Ingram, 1988) in they studied about survey of promotional practices indicates that many offices representing developing countries respond slowly to, or completely ignore, written requests for information on natureorientated tourism opportunities. Promotional material varies greatly in visual appeal and informational content. Different cultures have different ways of communicating, which in turn affects the stylistic features of Tourist Promotional Texts (TPTs). These stylistic differences pose a key challenge for translators of TPTs, whose role is to produce an effective translation in the target language and culture in order to persuade potential tourists in that language and culture (Sulaiman, 2014). (Ranginwala \& Towbin, 2017) says that the emergence of social media has provided medical practices with a new means of delivering content to a wide and varied audience. There are a number of different social media channels; however, each allows users to interact with each other, sharing and consuming content in a manner governed by rules unique to the specific social media platform.

\section{RESEARCH METHODE}

This type of research is qualitative research (Sugiyono, 2010, p. 9). The research was conducted at PT. Gili Pesona Sejahtera, Lombok, north of friends and teachers in research (Sugiyono, 2010). While in determining the sample or informant in this study using a snowball sampling as a sampling technique of data sources that initially amounted to a little longer to become large. In determining the way the sample is, the researcher selects certain people who are considered to be providing the necessary data; then based on the data or information obtained from the previous sample, researchers can determine other samples that are considered to provide more complete data. Based on the description, the subject of this research is the Manager of PT. Gili Pesona Sejahtera, Manager of Ningaloo villa, Manager of shine shell resort, and Manager of sad resort.

To get a representative research result, the data collection techniques used are observation, interview, and documentation. As for the data analysis process in this study, the author prefers the Miles and Huberman analysis model. Miles and Huberman in (Sugiyono, 2010) suggest that activities in qualitative data analysis are carried out interactively and take place continuously so that the data is saturated. The following are: Data Reduction; Presentation of Data (Display Data); Verification (Interesting Conclusions).

\section{RESULTS AND DISCUSSION}

PT. Gili Pesona Sejahtera is a company engaged in accommodation services such as hotels, restaurants, and tour and travel organizers located in Gili Trawangan, Gili Indah Village, Pemenang District, North Lombok Regency, West 
Nusa Tenggara Province. PT. Gili Pesona Sejahtera was established in 2013. Christine Arsy Yani is the founder of this company with experience and success in managing companies in Bogor, Bali, Jakarta, and Toraja. Christine Arsy also controls 50\% of the company's shares. PT. Gili Pesona Sejahtera has 60 staff and employees.

In managing the business activities of hotel accommodation, restaurant and tour \& Travers service providers, dynamic and competitive management is needed so that the company can achieve its objectives, namely efficient in the sense that in terms of costs, time and labor involved, there is no waste and effective in meaning that the production factors that work within the organization can create good working relationships among the personnel. An organization is a form of a partnership consisting of two or more people who work together to achieve a common goal.

PT. Gili Pesona Sejahtera is a hotel engaged in providing hotel room services, swimming pools, and restaurants. As a company engaged in the hospitality business, marketing activities are the most important factor in its role to increase the number of rooms used and facilities offered. Market conditions that increasingly lead to the sale of hotel rooms have become an obstacle for PT. Gili Pesona Sejahtera to anticipate the market competition, so that a marketing strategy that is oriented towards increasing sales and segmenting the domestic market is needed.

One element in the integrated marketing strategy is the marketing mix strategy or marketing mix that is related to assessing how the company presents and offers hotel service products in certain market segments that are its market target. In terms of pricing, the prices offered by PT. Gili Pesona Sejahtera ranges from Rp. 200,000 to Rp. 3,000,000. per night. classification of pricing is dependent on the packages offered such as backpacker, middle, and VIP packages. There are also daily, weekly, monthly and annual packages. Because according to the manager of PT. Gili Pesona Sejahtera itself, as long as the rooms are used then they also offer as requested by consumers.

The other marketing strategy is to collaborate with other hotel accommodation entrepreneurs such as; hotel owners, resorts, villas, cottages, bungalows, and guesthouses. PT. Gili Pesona Sejahtera and entrepreneurs form an organized alliance/group so that they can facilitate the arrangement and management of the distribution of the percentage of each member's commission, in this case, PT. Gili Pesona Sejahtera and entrepreneurs will also get the convenience to fill each other in the vacancies of hotel guests by offering each other suitable accommodation places when some overbooked guests or guests want to move to a place with a different atmosphere from the previous place. from the price of the room, so PT. Gili Pesona Sejahtera will benefit greatly from this method.

Whereas the products offered, in addition to lodging, PT. Gili Pesona Sejahtera also has a swimming pool and restaurant. The other marketing strategies of PT. Gili Pesona Sejahtera works with businessmen of travel agents and marine tourism entrepreneurs. Together with businessmen travel agents make it easier to sell tour packages offered such as VIP package deals where hotels organize from departure transport, hotels, land and sea tour tours (water sports, diving, snorkeling, horse riding, biking, Rinjani tracking, traditional Sasak village, waterfall, rice field 
views, motorbiking, and surfing) until the transfer back home. because the sale of tour packages will attract tourists interested because tourists only pay 1 tour package which includes everything without having to bother experimenting on their own to a strange place for them. Benefits of PT. Gili Pesona Sejahtera is very much with this method because it uses a price benchmark according to the agreement so that PT. Gili Pesona Sejahtera can freely manage prices.

Related to marketing strategies in terms of promotions carried out through advertising. Also, to further increase the number of subscribers, PT. Gili Pesona Sejahtera cooperates with internet marketing entrepreneurs, social media, and room guides offline. in today's technological era, the internet is one of the most important things needed by modern-day people today, which as we know the internet provides all kinds of information needed easily, from that gap we rely on internet marketing entrepreneurs like google with booking.com, air BnB, traveloka, Facebook, Instagram, twitter which are the most popular with the most website accessors so that they can make it easier to attract more guests. there are various commission fees that they offer from $10 \%$ to $18 \%$ but help the company in increasing revenue compared to the cheaper cost offline room guide which is $5 \%$. Offline room guides are also very helpful in increasing the company's income where they guide guests who have just arrived at the port and have not booked rooms like backpacker tourists who always vacation independently.

To maintain customers, PT. Gili Pesona Sejahtera always prepares to improve the place and quality of service. The most important thing to do in marketing is not just selling products and services that are only enjoyed once, but how PT. Gili Pesona Sejahtera seeks to maintain the customer itself. The program is gathering which aims to bring PT. Gili Pesona Sejahtera with loyal customers or successful teams such as travel agents that bridge consumers with PT. Gili Pesona Sejahtera.

\section{E. CONCLUSION}

From the results of the research and analysis of researchers, it can be concluded that it is known that PT. Gili Pesona Sejahtera is in a strategic place for the survival of its company, so it has a strong competitive market position in an attractive industry. This shows that PT. Gili Pesona Sejahtera must continue to make efforts to improve product quality, facilities, services, and product distribution. Overall, PT. Gili Pesona Sejahtera is currently a company that is quite successful in the hospitality industry, especially three-star hotels. Besides that, PT. Gili Pesona Sejahtera is also supported by good internal strength and equal service with five-star hotels, professional resource support, and good management support under the management of PT. Gili Pesona Sejahtera. There is a marketing strategy applied by PT. Gili Pesona Sejahtera is related to business development and changes in market conditions that occur, namely PT. Gili Pesona Sejahtera in its operations in collaboration with accommodation entrepreneurs which include hoteliers, travel agent entrepreneurs, water entrepreneurs, internet marketing entrepreneurs, and room guides offline. The recommendation of this study is that hotel managers in tourism areas should always pay attention to aspects of customer satisfaction, as well as continue and continue to pay attention to environmental 
safety and sustainability of tourism activities while continuing to prioritize local wisdom that has been running

\section{REFERENCE}

Ardelean, C. F., Becerra-Valdivia, L., Pedersen, M. W., Schwenninger, J.-L., Oviatt, C. G., Macías-Quintero, J. I., Arroyo-Cabrales, J., Sikora, M., Ocampo-Díaz, Y. Z. E., Rubio-Cisneros, I. I., Watling, J. G., de Medeiros, V. B., De Oliveira, P. E., Barba-Pingarón, L., Ortiz-Butrón, A., BlancasVázquez, J., Rivera-González, I., Solís-Rosales, C., Rodríguez-Ceja, M., ... Willerslev, E. (2020). Evidence of human occupation in Mexico around the Last Glacial Maximum. Nature, 1-6. https://doi.org/10.1038/s41586-0202509-0

Betari Avinda, C., Sudiarta, I. N., \& Oka Karini, N. M. (2016). Strategi Promosi Banyuwangi Sebagai Destinasi Wisata (Studi Kasus Pada Dinas Kebudayaan Dan Pariwisata). Jurnal IPTA, 4(1), 55. https://doi.org/10.24843/ipta.2016.v04.i01.p10

Dudensing, R. M., Hughes, D. W., \& Shields, M. (2011). Perceptions of tourism promotion and business challenges: A survey-based comparison of tourism businesses and promotion organizations. Tourism Management, 32(6), 14531462. https://doi.org/10.1016/j.tourman.2010.10.008

Durst, P. B., \& Ingram, C. D. (1988). Nature-orientated tourism promotion by developing countries. Tourism Management, 9(1), 39-43. https://doi.org/10.1016/0261-5177(88)90056-8

Figueiredo, J., Cardoso, A., Pocinho, M., Rodrigues, P., \& Oliveira, I. (2019). Webmarketing triggering entrepreneurial behaviour. International Journal of Entrepreneurship, 23(3), 1-11.

Giménez-Meseguer, J., Tortosa-Martínez, J., \& Cortell-Tormo, J. M. (2020). The Benefits of Physical Exercise on Mental Disorders and Quality of Life in Substance Use Disorders Patients. Systematic Review and Meta-Analysis. International Journal of Environmental Research and Public Health, 17(10), 3680. https://doi.org/10.3390/ijerph17103680

Haidari, M., Etemad, V., \& Khosropour, E. (2013). Study of tree regeneration in the grazed and non-grazed areas in the Iran-o-Turanian Ecological Zones. International Journal of Advanced Biological and Biomedical Research (IJABBR), 1(1), 18-24. http://www.ijabbr.com/article_6566.html

Hurriyati, R. (2010). Open Library - Bauran Pemasaran dan Loyalitas Konsumen: Fokus pada Konsumen Kartu Kredit Perbankan. Alfabeta. https://openlibrary.telkomuniversity.ac.id/pustaka/6696/bauran-pemasarandan-loyalitas-konsumen-fokus-pada-konsumen-kartu-kredit-perbankan.html

Liu, Y., Hultman, M., Eisingerich, A. B., \& Wei, X. (2020). How does brand loyalty interact with tourism destination? Exploring the effect of brand loyalty on 
place attachment. Annals of Tourism Research, 81, 102879. https://doi.org/10.1016/j.annals.2020.102879

Matiza, T., \& Slabbert, E. (2020). South Africa's place brand: A marketing axiom to South Africa as a tourism destination? Journal of Destination Marketing and Management, 15, 100380. https://doi.org/10.1016/j.jdmm.2019.100380

Njoku, K. C., \& Cooney, T. M. (2020). How Does the Man-Know-Man Network Culture Influence Transnational Entrepreneurship? Journal of Entrepreneurship and Innovation in Emerging Economies, 6(1), 163-181. https://doi.org/10.1177/2393957519891041

Rahim, M. A., Ma, Z., Quah, C. S., Rahman, M. S., Jasimuddin, S. M., Shaw, L., \& Ozyilmaz, A. (2019). Intelligent entrepreneurship and firm performance: A cross-cultural investigation. Journal of International Entrepreneurship, 17(4), 475-493. https://doi.org/10.1007/s10843-019-00252-5

Ranginwala, S., \& Towbin, A. J. (2017). The Power of Promotion: Using Social Media to Promote a Radiology Department. Academic Radiology, 24(4), 488496. https://doi.org/10.1016/j.acra.2016.11.011

Sugiyono. (2010). Metode Penelitian Kuantitatif, Kualitatif, Dan R \& D. Alfabeta. https://onesearch.id/Record/IOS3767.JATEN000000120000706\#details

Sulaiman, M. Z. (2014). Translating the Style of Tourism Promotional Discourse: A Cross Cultural Journey into Stylescapes. Procedia - Social and Behavioral Sciences, 118, 503-510. https://doi.org/10.1016/j.sbspro.2014.02.069

Suprapto, H. (2019). Analisis Strategi Pemasaran Dalam Menghadapi Persaingan Antar Jasa Penginapan Di Kota Lamongan (Studi Pada Hotel Mahkota Lamongan). Jurnal Penelitian Ilmu Manajemen, 4(3), 1049-1060. https://doi.org/10.1017/CBO9781107415324.004

Vada, S., Prentice, C., \& Hsiao, A. (2019). The influence of tourism experience and well-being on place attachment. Journal of Retailing and Consumer Services, 47, 322-330. https://doi.org/10.1016/j.jretconser.2018.12.007

Wang, S., \& Xu, H. (2015). Influence of place-based senses of distinctiveness, continuity, self-esteem and self-efficacy on residents' attitudes toward tourism. Tourism Management, 47, 241-250. https://doi.org/10.1016/j.tourman.2014.10.007

$\mathrm{Xu}, \mathrm{K}$., Drennan, J., \& Mathews, S. (2019). Immigrant entrepreneurs and their cross-cultural capabilities: A study of Chinese immigrant entrepreneurs in Australia. Journal of International Entrepreneurship, 17(4), 520-557. https://doi.org/10.1007/s10843-019-00261-4 